\title{
Pathotyping and AFLP-based molecular characterization of Macrophomina phaseolina isolates from different plant hosts
}

\author{
Alghuthaymi MA ${ }^{1}$, Aly $\mathrm{AA}^{2}$, Asran-Amal A and Abd-Elsalam KA $\mathrm{A}^{2,3^{*}}$ \\ ${ }^{1}$ Department of Biology, Science and Humanities College, Alquwayiyah, Shaqra University, Saudi Arabia \\ ${ }^{2}$ Plant Pathology Research Institute, Agricultural Research Center (ARC), Egypt \\ ${ }^{3}$ Unit of Excellence in Nano-Molecular Plant Pathology Research (ARC), Egypt
}

Alghuthaymi MA, Aly AA, Asran-Amal A, Abd-Elsalam KA 2016 - Pathotyping and AFLP-based molecular characterization of Macrophomina phaseolina isolates from different plant hosts. Plant Pathology \& Quarantine 6(1), 31-41, Doi 10.5943/ppq/6/1/5

\begin{abstract}
Ninety-six isolates of Macrophomina phaseolina, from five different hosts, were tested for pathogenicity on seedlings of cotton (Gossypuim barbadense L.) cultivar Giza 89 under greenhouse conditions. Of the cotton isolates, 73 were pathogenic representing $98.65 \%$ of the cotton isolates, $76.04 \%$ of the total isolates, and $76.84 \%$ of the pathogenic isolates from all hosts. The pathogenic isolates of the other hosts ranged from four to seven. The percentage of isolates, which significantly affected post-emergence damping-off, was much greater than that of the isolates which significantly affected pre-emergence damping-off or plant height. Dry weight was not affected by any of the tested isolates. A highly significant negative correlation was observed between postemergence damping-off and survival. Grouping the isolates by cluster analysis based on pathogenicity was neither related to their geographic origins nor to hosts. AFLP was used to evaluate the genetic diversity among the isolates. In this analysis, polymerase chain reaction was performed by using four AFLP primers. Grouping the isolates by cluster analysis based on AFLP banding patterns was also neither related to their geographic origins nor to hosts. These results may suggest that isolates of $M$. phaseolina from each geographic origin or host were a heterogeneous group of isolates.
\end{abstract}

Key words - AFLP markers - charcoal rot - Macrophomina phaseolina - pathogenicity

\section{Introduction}

Charcoal rot is caused by Macrophomina phaseolina (Tassi) Goid., which is considered one of the most destructive necrotrophic plant pathogens. It has a broad host range infecting about 500 plant species in more than 100 families throughout the world (Mihail \& Taylor 1995, Su et al. 2001, Saleh et al. 2010). It can also infect many native plants and it is an adaptable pathogen of human beings (Tan et al. 2008). M. phaseolina has been recorded on cotton in south-eastern USA in Oklahoma and Texas (Watkins 1981), but is of little economic significance there compared to the Indian subcontinent, East and Central Africa, and elsewhere in the tropics and sub-tropics (Suriachandraselvan et al. 2005, Omar et al. 2007). The severity of charcoal rot on cotton in Pakistan, India, the Sudan, and Central Africa may be linked to soil moisture deficit and hot 
weather (Watkins 1981). The importance of M. phaseolina as a cotton pathogen in Egypt is undervalued (Omar et al. 2007, Abd-Elsalam 2010, Asran-Amal 2012). This vision has come from the observation that during the last 50 years, $M$. phaseolina on cotton was almost absent from the literature of cotton diseases in Egypt. Thus, a handful of studies, most of them not dealing with $M$. phaseolina per se, has been published (Mostafa 1959, Mohamed 1962, Sabet \& Khan 1969, Omar et al. 2007). This lack of concern is not justifiable because this fungal pathogen is of a widespread distribution in Egyptian soils and it is commonly isolated from cotton roots particularly late in the growing season. Pathogenicity of the fungus on commercial cotton cultivars in Egypt has been confirmed (Omar et al. 2007, Abd-Elsalam 2010).

Molecular tools have been used to examine the genetic variation of $M$. phaseolina isolates in order to categorize them into specific groups (Jana et al. 2005). Amplified fragment length polymorphism (AFLP) analysis is valuable in revealing genetic variability in the fungal populations and has been used to study genetic diversity in populations of $M$. phaseolina in several countries including Australia (Fuhlbohm 1997), Mexico (Vandemark et al. 2000, Mayék-Pérez et al. 2001), Brazil (Almeida et al. 2003), USA (Brooker et al. 2008) and China (Linhai et al. 2011). In Egypt, resistance to M. phaseolina is totally lacking in the commercial cotton cultivars (Omar et al. 2007). A clear understanding of the extent of genetic variation among M. phaseolina isolates would be helpful in developing resistant cotton cultivars. Therefore, the objectives of this investigation were (1) to assess pathogenicity of $M$. phaseolina isolates from different hosts on the seedlings of the commercial cotton cultivar Giza 89 under greenhouse conditions, and (2) to assess genetic diversity differences among these isolates by AFLP analysis.

\section{Materials \& Methods}

\section{Fungal isolates and inoculum production}

Pathological studies and genetic variation in 96 isolates of Macrophomina phaseolina obtained from the fungal collection of the Cotton and Fiber Crops Diseases Research Section, Plant Pathology Research Institute, Agricultural Research Center, Giza, Egypt were evaluated. Most isolates were originally isolated from cotton roots (Table 1).

Table 1 Geographic origins, hosts, cotton cultivars and variables used in testing pathogenicity of Macrophomina phaseolina isolates used in this study.

\begin{tabular}{|c|c|c|c|c|c|c|c|c|}
\hline \multirow[b]{2}{*}{$\begin{array}{c}\text { Isolate } \\
\text { no. }\end{array}$} & \multirow[b]{2}{*}{$\begin{array}{l}\text { Geographic } \\
\text { origin }\end{array}$} & \multirow[b]{2}{*}{ Host } & \multirow[b]{2}{*}{ Cultivar } & \multicolumn{5}{|c|}{ Pathogenicity variables } \\
\hline & & & & $\begin{array}{c}\text { Pre-emergence } \\
\text { damping-off }^{\mathrm{a}} \\
\%\end{array}$ & $\begin{array}{c}\begin{array}{c}\text { Post-emergence } \\
\text { damping-off }^{\mathrm{a}} \\
\%\end{array} \\
\end{array}$ & $\begin{array}{c}\text { Survival }^{\mathrm{a}} \\
\%\end{array}$ & $\begin{array}{c}\begin{array}{c}\text { Plant } \\
\text { height } \\
\mathrm{cm} / \text { plant }\end{array} \\
\end{array}$ & $\begin{array}{c}\text { Dry } \\
\text { weight } \\
\text { mg/plan }\end{array}$ \\
\hline 1 & Giza & Cotton & Giza 75 & $40.61 *$ & $29.73 *$ & $40.61 *$ & 27.03 & 276.75 \\
\hline 2 & Minufiya & Cotton & Giza 75 & 28.22 & $34.56^{*}$ & $46.51 *$ & 22.91 & 241.00 \\
\hline 3 & Minufiya & Cotton & Giza 75 & 24.53 & $33.05 *$ & $49.61 *$ & 23.10 & 258.00 \\
\hline 4 & Daqahliya & Cotton & Giza 75 & 31.39 & $29.89 *$ & $45.00 *$ & 25.61 & 271.00 \\
\hline 5 & Daqahliya & Cotton & Giza 75 & 24.53 & $26.19 *$ & $49.39 *$ & 26.44 & 317.50 \\
\hline 6 & Minufiya & Cotton & Giza 75 & $34.56^{*}$ & $22.50 *$ & $42.12 *$ & 25.61 & 301.00 \\
\hline 7 & Giza & Cotton & Giza 75 & 26.19 & $38.89 *$ & $40.39 *$ & 24.32 & 280.50 \\
\hline 8 & Kafr El-sheikh & Cotton & Giza 86 & $34.72 *$ & $37.66^{*}$ & $34.72 *$ & 21.83 & 232.75 \\
\hline 9 & Beheira & Cotton & Giza 75 & 31.55 & $24.16^{*}$ & $46.38 *$ & 24.50 & 322.50 \\
\hline 10 & Gharbiya & Cotton & Giza 75 & 31.39 & $33.21 *$ & $46.51 *$ & 21.30 & 261.25 \\
\hline 11 & Kafr El-shaikh & Cotton & Giza 86 & 25.83 & $40.45^{*}$ & $35.94 *$ & 21.29 & 274.50 \\
\hline 12 & Daqahliya & Cotton & Giza 75 & $34.72 *$ & $33.97 *$ & $36.92 *$ & 18.66 & 255.00 \\
\hline 13 & Gharbiya & Cotton & Giza 75 & $36.92 *$ & $42.12 *$ & $24.16^{*}$ & 22.98 & 244.75 \\
\hline 14 & Minya & Cotton & Giza 80 & $37.66^{*}$ & $20.47 *$ & $45.00 *$ & 25.63 & 355.00 \\
\hline 15 & Kafr El-sheikh & Cotton & Giza 86 & $33.05^{*}$ & $33.21 *$ & $39.17 *$ & 22.42 & 226.25 \\
\hline 16 & Giza & Cotton & Giza 86 & $36.00 *$ & $29.89 *$ & $39.17 *$ & 23.17 & 233.25 \\
\hline 17 & Assiut & Cotton & Giza 83 & 24.53 & $31.55^{*}$ & $47.89 *$ & 21.38 & 352.50 \\
\hline 18 & Sharqiya & Cotton & Giza 85 & 28.22 & $39.17 *$ & $37.73 *$ & 23.96 & 232.50 \\
\hline 19 & Damietta & Cotton & Giza 45 & 31.55 & $28.22 *$ & $45.00 *$ & 22.76 & 204.00 \\
\hline
\end{tabular}


Table 1 continued

\begin{tabular}{|c|c|c|c|c|c|c|c|c|}
\hline \multirow[b]{2}{*}{$\begin{array}{c}\text { Isolate } \\
\text { no. }\end{array}$} & \multirow[b]{2}{*}{$\begin{array}{l}\text { Geographic } \\
\text { origin }\end{array}$} & \multirow[b]{2}{*}{ Host } & \multirow[b]{2}{*}{ Cultivar } & \multicolumn{5}{|c|}{ Pathogenicity variables } \\
\hline & & & & $\begin{array}{c}\text { Pre-emergence } \\
\text { damping-off } \\
\%\end{array}$ & $\begin{array}{c}\begin{array}{c}\text { Post-emergence } \\
\text { damping-off }\end{array} \\
\%\end{array}$ & $\begin{array}{c}\text { Survival }^{\mathrm{a}} \\
\%\end{array}$ & $\begin{array}{c}\text { Plant } \\
\text { height } \\
\mathrm{cm} / \text { plant }\end{array}$ & $\begin{array}{c}\text { Dry } \\
\text { weight } \\
\text { mg/plant }\end{array}$ \\
\hline 20 & Minufiya & Cotton & Giza 86 & 29.89 & $34.72 *$ & $40.61 *$ & 21.98 & 287.75 \\
\hline 21 & Minufiya & Cotton & Giza 86 & $49.33^{*}$ & $22.50 *$ & $31.55^{*}$ & 24.33 & 280.50 \\
\hline 22 & Minufiya & Cotton & Giza 75 & 28.22 & $28.22 *$ & $47.89 *$ & 20.75 & 288.75 \\
\hline 23 & Beheira & Cotton & Giza 75 & $47.89 *$ & $33.21 *$ & $22.50^{*}$ & 24.04 & 221.00 \\
\hline 24 & Daqahliya & Cotton & Giza 84 & 28.22 & $36.17 *$ & $42.05 *$ & 27.18 & 237.00 \\
\hline 25 & Daqahliya & Cotton & Giza 84 & 28.22 & $37.73 *$ & $39.23^{*}$ & 22.69 & 239.50 \\
\hline 26 & Minufiya & Cotton & Giza 75 & 22.50 & $37.73 *$ & $43.56^{*}$ & 24.68 & 304.25 \\
\hline 27 & Gharbiya & Cotton & Giza 86 & $36.23^{*}$ & $45.00 *$ & $22.50^{*}$ & 23.99 & 285.75 \\
\hline 28 & Daqahliya & Cotton & Giza 75 & $43.56^{*}$ & $40.67 *$ & $31.39 *$ & 21.67 & 325.75 \\
\hline 29 & Daqahliya & Cotton & Giza 86 & 29.89 & $46.44 *$ & $15.86^{*}$ & 18.95 & 191.25 \\
\hline 30 & Minufiya & Cotton & Giza 75 & $43.56^{*}$ & 9.22 & $43.56^{*}$ & 24.91 & 365.50 \\
\hline 31 & Minya & Cotton & Giza 80 & $49.33 *$ & $29.89 *$ & $24.53^{*}$ & 23.00 & 229.75 \\
\hline 32 & Giza & Cotton & Giza 86 & $39.17 *$ & $42.05^{*}$ & $19.55^{*}$ & 16.43 & 291.75 \\
\hline 33 & Damietta & Cotton & Giza 45 & $47.89 *$ & $39.17 *$ & $9.22 *$ & $12.26^{*}$ & 154.00 \\
\hline 34 & Gharbiya & Cotton & Giza 75 & $49.33^{*}$ & $27.33^{*}$ & $29.89 *$ & 21.77 & 249.50 \\
\hline 35 & Qualyubiya & Cotton & Giza 85 & $43.50 *$ & $48.01 *$ & $20.47 *$ & 20.13 & 231.75 \\
\hline 36 & Daqahliya & Cotton & Giza 75 & 36.22 & $52.40 *$ & $33.21^{*}$ & 20.46 & 275.50 \\
\hline 37 & Sharqiya & Cotton & Giza 85 & 28.22 & $43.56^{*}$ & $13.28^{*}$ & $10.20 *$ & 138.50 \\
\hline 38 & Assiut & Cotton & Giza 83 & 22.50 & $40.61 *$ & $18.44^{*}$ & 21.75 & 212.50 \\
\hline 39 & Assiut & Cotton & Giza 83 & 19.92 & $39.23^{*}$ & $37.73^{*}$ & 24.35 & 279.00 \\
\hline 40 & Assiut & Cotton & Giza 83 & 9.22 & $42.75^{*}$ & $40.61^{*}$ & 22.70 & 290.25 \\
\hline 41 & Assiut & Cotton & Giza 83 & $33.90 *$ & $42.05^{*}$ & $47.89 *$ & 22.75 & 251.75 \\
\hline 42 & Assiut & Cotton & Giza 83 & 24.16 & $38.95^{*}$ & $17.30^{*}$ & $11.95^{*}$ & 122.75 \\
\hline 43 & Assiut & Cotton & Giza 83 & 29.36 & $24.53 *$ & $46.50^{*}$ & 23.46 & 180.50 \\
\hline 44 & Gharbiya & Cotton & Giza 75 & 24.16 & $42.59 *$ & $22.50^{*}$ & 18.00 & 197.75 \\
\hline 45 & Sohag & Cotton & Giza 83 & $39.11 *$ & $14.42 *$ & $40.39 *$ & 17.35 & 126.25 \\
\hline 46 & Assiut & Cotton & Giza 83 & $42.05^{*}$ & $25.67 *$ & $35.19 *$ & 22.19 & 254.75 \\
\hline 47 & Assiut & Cotton & Giza 83 & 4.61 & $22.50 *$ & 65.70 & 24.09 & 222.50 \\
\hline 48 & Assiut & Cotton & Giza 83 & 14.94 & $27.70 *$ & 54.53 & 23.40 & 233.25 \\
\hline 49 & Assiut & Cotton & Giza 83 & 23.25 & $52.56^{*}$ & $17.30^{*}$ & $11.81 *$ & 120.25 \\
\hline 50 & Assiut & Cotton & Giza 83 & 17.52 & $64.18^{*}$ & $11.25^{*}$ & $12.88 *$ & 100.75 \\
\hline 51 & Sohag & Cotton & Giza 83 & 15.86 & $33.91 *$ & $49.39 *$ & 24.63 & 333.00 \\
\hline 52 & Sohag & Cotton & Giza 83 & 20.47 & $25.67 *$ & $55.73^{*}$ & 22.05 & 330.75 \\
\hline 53 & Sohag & Cotton & Giza 83 & 24.53 & $51.05^{*}$ & 23.25 & 17.77 & 182.25 \\
\hline 54 & Sohag & Cotton & Giza 83 & 33.05 & $32.53^{*}$ & $33.05^{*}$ & 27.14 & 281.75 \\
\hline 55 & Sohag & Cotton & Giza 83 & 19.92 & $26.52 *$ & 52.93 & 24.51 & 226.25 \\
\hline 56 & Assiut & Cotton & Giza 83 & 27.86 & 39.80 & $31.50^{*}$ & 18.29 & 123.50 \\
\hline 57 & Assiut & Cotton & Giza 83 & 17.52 & $27.86^{*}$ & 54.53 & 23.50 & 214.25 \\
\hline 58 & Damietta & Cotton & Giza 75 & 19.55 & $21.22 *$ & 55.73 & 23.63 & 223.50 \\
\hline 59 & Assiut & Cotton & Giza 83 & 14.94 & $46.51 *$ & $36.00^{*}$ & 24.58 & 205.50 \\
\hline 60 & Sohag & Cotton & Giza 83 & 19.55 & 9.22 & 64.33 & 24.60 & 277.00 \\
\hline 61 & Assiut & Cotton & Giza 83 & 21.06 & $26.19 *$ & $52.56^{*}$ & 21.1 & 204.25 \\
\hline 62 & Minya & Cotton & Giza 80 & 25.67 & $36.00 *$ & $41.83^{*}$ & 23.15 & 200.75 \\
\hline 63 & Sohag & Cotton & Giza 83 & 24.53 & $35.41 *$ & $43.34 *$ & 24.00 & 178.75 \\
\hline 64 & Sohag & Cotton & Giza 83 & $37.44 *$ & $37.66^{*}$ & $29.36^{*}$ & 22.15 & 196.25 \\
\hline 65 & Assiut & Cotton & Giza 83 & 17.52 & $39.87^{*}$ & $42.64 *$ & 22.73 & 272.75 \\
\hline 66 & Sohag & Cotton & Giza 83 & 24.16 & $31.02 *$ & $51.05^{*}$ & 21.67 & 217.75 \\
\hline 67 & Assiut & Cotton & Giza 83 & 26.19 & $23.25^{*}$ & $50.90^{*}$ & 24.96 & 243.50 \\
\hline 68 & Assiut & Cotton & Giza 83 & $34.50 *$ & $31.02 *$ & $38.95^{*}$ & 24.27 & 221.00 \\
\hline 69 & Assiut & Cotton & Giza 83 & 9.22 & $27.33^{*}$ & $59.14^{*}$ & 23.45 & 220.00 \\
\hline 70 & Sohag & Cotton & Giza 83 & 22.50 & $26.19 *$ & $45.00 *$ & 22.68 & 239.25 \\
\hline 71 & Minufiya & Cotton & Giza 75 & 24.53 & $39.17 *$ & $40.61^{*}$ & 23.29 & 265.25 \\
\hline 72 & Sharqiya & Cotton & Giza 85 & 24.16 & $33.05^{*}$ & $46.51 *$ & 23.15 & 248.00 \\
\hline 73 & Sharqiya & Cotton & Giza 85 & 26.19 & $25.67 *$ & 54.00 & 22.88 & 223.75 \\
\hline 74 & Beheira & Cotton & Giza 75 & 17.52 & $47.89 *$ & $34.50 *$ & 21.99 & 263.75 \\
\hline
\end{tabular}




\begin{tabular}{|c|c|c|c|c|c|c|c|c|}
\hline \multirow[b]{2}{*}{$\begin{array}{c}\text { Isolate } \\
\text { no. }\end{array}$} & \multirow[b]{2}{*}{$\begin{array}{l}\text { Geographic } \\
\text { origin }\end{array}$} & \multirow[b]{2}{*}{ Host } & \multirow[b]{2}{*}{ Cultivar } & \multicolumn{5}{|c|}{ Pathogenicity variables } \\
\hline & & & & $\begin{array}{c}\text { Pre-emergence } \\
\text { damping-off }^{\mathrm{a}} \\
\%\end{array}$ & $\begin{array}{c}\begin{array}{c}\text { Post-emergence } \\
\text { damping-off }^{\mathrm{a}} \\
\%\end{array} \\
\end{array}$ & $\begin{array}{c}\text { Survival }^{a} \\
\%\end{array}$ & $\begin{array}{c}\begin{array}{c}\text { Plant } \\
\text { height } \\
\mathrm{cm} / \text { plant }\end{array} \\
\end{array}$ & $\begin{array}{c}\begin{array}{c}\text { Dry } \\
\text { weight } \\
\text { mg/plant }\end{array} \\
\end{array}$ \\
\hline 75 & Netherlands & Flax & unknown & 29.36 & $34.56 *$ & $39.17 *$ & 23.54 & 229.25 \\
\hline 76 & Giza & Flax & unknown & $38.95 *$ & $34.61 *$ & $22.50 *$ & $10.12 *$ & 151.50 \\
\hline 77 & Beheira & Flax & unknown & 25.67 & $19.54 *$ & 53.78 & 24.69 & 195.25 \\
\hline 78 & Sharqiya & Flax & unknown & $17.89 *$ & $25.83^{*}$ & 55.51 & 22.63 & 256.75 \\
\hline 79 & Daqahliya & Flax & unknown & 32.31 & $28.55^{*}$ & $38.20 *$ & 17.08 & 182.00 \\
\hline 80 & Netherlands & Flax & unknown & 21.22 & $32.47 *$ & $46.51 *$ & 24.58 & 272.00 \\
\hline 81 & Giza & Sesame & unknown & 25.67 & $30.22 *$ & $42.97 *$ & 18.75 & 130.25 \\
\hline 82 & Faiyum & Sesame & unknown & 17.89 & $25.67 *$ & $41.48 *$ & 24.09 & 235.75 \\
\hline 83 & Giza & Sesame & unknown & 24.53 & $23.09 *$ & 53.08 & 22.22 & 241.00 \\
\hline 84 & Faiyum & Sesame & unknown & 24.53 & $29.89 *$ & $49.39 *$ & 24.92 & 221.00 \\
\hline 85 & Giza & Sesame & unknown & 11.25 & $24.75^{*}$ & 57.47 & 23.79 & 217.25 \\
\hline 86 & Beheira & Sesame & unknown & $33.05^{*}$ & $26.19 *$ & $41.91 *$ & 23.65 & 222.25 \\
\hline 87 & Giza & Sesame & unknown & 27.70 & 22.50 & $52.50 *$ & 23.38 & 220.00 \\
\hline 88 & Giza & Sunflower & unknown & 24.53 & $43.72 *$ & $32.25^{*}$ & 16.72 & 140.50 \\
\hline 89 & Giza & Sunflower & unknown & 15.86 & 14.42 & $47.94 *$ & 24.83 & 206.75 \\
\hline 90 & Giza & Sunflower & unknown & 19.55 & $35.94 *$ & $45.00 *$ & 23.90 & 208.50 \\
\hline 91 & Giza & Sunflower & unknown & 24.16 & $37.44 *$ & $41.25^{*}$ & 24.47 & 231.50 \\
\hline 92 & Giza & Sunflower & unknown & 22.50 & $34.50 *$ & $46.38 *$ & 21.92 & 256.25 \\
\hline 93 & Giza & Soybean & unknown & 31.55 & $17.52 *$ & $44.94 *$ & 26.17 & 274.00 \\
\hline 94 & Giza & Soybean & unknown & 24.16 & $29.36^{*}$ & $49.61 *$ & 23.65 & 281.00 \\
\hline 95 & Giza & Soybean & unknown & 31.39 & $21.58 *$ & $50.83^{*}$ & 19.92 & 272.50 \\
\hline 96 & Giza & Soybean & unknown & 27.33 & $34.28 *$ & $41.31 *$ & 23.25 & 220.50 \\
\hline Control & & & & 15.86 & 0.00 & 74.14 & 22.00 & 251.75 \\
\hline $\operatorname{LSD}(\mathrm{p} \leq$ & $0.05)$ & & & 12.41 & 15.06 & 17.61 & 7.62 & NS \\
\hline
\end{tabular}

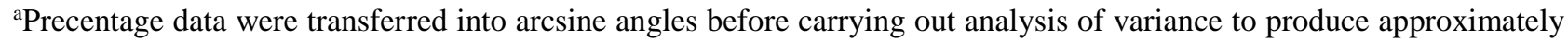
constant variance. An asterisk denotes a significant difference from the control.

A substrate for growth of isolates was prepared in $500 \mathrm{ml}$ glass bottles; each bottle contained $40 \mathrm{~g}$ of sorghum grains and $50 \mathrm{ml}$ of tap water. Contents of each bottle were autoclaved for $30 \mathrm{~min}$ at $125^{\circ} \mathrm{C}$. Isolate inoculum, taken from one-week-old cultures on potato dextrose agar (PDA) medium, was aseptically introduced into the bottle and allowed to colonize the substrate for 3 weeks at $25^{\circ} \mathrm{C}$. Inoculum was air-dried and stored in plastic bags at $10^{\circ} \mathrm{C}$. Inoculum level was $50 \mathrm{~g}$ of fungus/sorghum mixture/kg of soil.

\section{Pathogenicity test of $M$. phaseolina isolates}

Pathogenicity assay was carried out using autoclaved clay-based loam soil. Batches of soil were separately infested with inoculum of each isolate at a rate of $50 \mathrm{~g} / \mathrm{kg}$ of soil. In the control treatment, autoclaved soil was infested with autoclaved sorghum grains at rate of $50 \mathrm{~g} / \mathrm{kg}$ of soil. Pots were planted with 10 seeds per pot for each of cv. Giza 89. Pots were randomly distributed on greenhouse benches under a temperature regime ranging from $19.5 \pm 1.5$ to $34 \pm 4^{\circ} \mathrm{C}$. There were three pots (replicates) for each isolate. Pre-emergence damping-off was recorded 15 days after planting, post-emergence damping-off, survival, plant height $(\mathrm{cm})$, and dry weight $(\mathrm{mg} / \mathrm{plant})$ were recorded 45 days after planting. The trial was replicated twice with almost the same results.

\section{Statistical analysis of the data}

Randomized complete block experimental design with three replicates was subjected to analysis of variance (ANOVA) and correlation using MSTAT-C Statistical Package. The least significant difference (LSD) was used to compare isolate means. Percentage data were transformed into arc sine angles before carrying out the ANOVA to normalize data and stabilize variances 
throughout the data range. Cluster analysis of M. phaseolina isolates was performed using software package SPSS 13.

\section{DNA isolation}

Hyphal tip cultures were transferred to PDA plates and incubated for 4 days and then transferred to a flask with $25 \mathrm{ml}$ potato dextrose broth and grown on a shaker at $75 \mathrm{rpm}$ for 5 days. The mycelia were harvested by filtration through a double layer of cheese cloth and freeze dried under vacuum. Frozen mycelium was ground in liquid nitrogen to a fine powder. Total genomic DNA was extracted as described by Abd-Elsalam et al. (2011).

\section{AFLP analysis}

AFLP analysis was accomplished as previously described by Abd-Elsalam et al. (2004). In short, DNA (50 ng) was digested with EcoRI and MseI and the resulting fragments were ligated to double-stranded adapters (EcoRI-adapter: 5' CTC GTA GAC TGC GTA CC 3' plus 3' CTG ACG CAT GGT TAA 5' and MseI-adapter: 5' GAC GAT GAG TCC TGA G 3' plus 3' TAC TCA GGA CTC AT 5', respectively). The digested and ligated DNA was then amplified by PCR (30 cycles) by using the EcoRI and MseI primers in a final volume of $50 \mu 1$ (EcoRI primer: 5' GTA GAC TGC GTA CCA ATT C 3', MseI primer: 5' GAC GAT GAG TCC TGA GTA A 3'). The PCR cycling conditions included the cycling profile of $94^{\circ} \mathrm{C}$ for $30 \mathrm{~s}, 60^{\circ} \mathrm{C}$ for $30 \mathrm{~s}$ and $72^{\circ} \mathrm{C}$ for $60 \mathrm{~s}$ repeated for 30 cycles. Three microliter were used in subsequent selective amplifications with the primer combination of EcoRI-C (5' GTA GAC TGC GTA CCA ATT CC 3') and MseI-G (5' GAC GAT GAG TCC TGA GTA AG 3'). Selective amplifications were performed in $20 \mu 1$ reaction mixtures using a cycling profile of $94^{\circ} \mathrm{C}$ for $30 \mathrm{~s}, 65^{\circ} \mathrm{C}$ for $30 \mathrm{~s}$ and $72^{\circ} \mathrm{C}$ for $1 \mathrm{~min}$ for one cycle and then lowering the annealing temperature by $1^{\circ} \mathrm{C}$ each cycle to $56^{\circ} \mathrm{C}$ (nine cycles), followed by additional 26 cycles at a $56^{\circ} \mathrm{C}$ annealing temperature.

Equal volumes of amplified product $(3 \mu \mathrm{l})$ and loading buffer $(95 \%$ formamide, $20 \mathrm{mmol} / \mathrm{l}$ EDTA, $0.05 \%$ bromophenol blue, $0.05 \%$ xylene cyanol) were mixed, then heated at $95^{\circ} \mathrm{C}$ for 3 min and snap-cooled on ice. The amplified fragments were separated in a denaturing $6 \%$ polyacrylamide sequencing gel with $8 \mathrm{~mol} / \mathrm{l}$ ultrapure urea (Roth, Germany). Electrophoresis was performed with a nucleic acid sequencing unit (Model Base Runner 100, Sigma-Aldrich, Germany) at $55 \mathrm{~W}$ with $1 \times$ Tris-Borate-EDTA ( $1 \times$ solution contains $89 \mathrm{mmol} / \mathrm{l} \mathrm{Tris,} 89 \mathrm{mmol} / \mathrm{l}$ boric acid and $2.0 \mathrm{mmol} / \mathrm{l}$ EDTA) as a running buffer. After electrophoresis, AFLP fingerprints were detected by silver staining protocol described by Creste et al. (2001). DNA patterns obtained by AFLP were clustered by a gel documentation system (Uvitec, Cambride, UK).

\section{Results}

\section{Pathogenicity test}

Ninety-six isolates of $M$. phaseolina from different hosts were tested for pathogenicity on seedlings of cotton cultivar Giza 89 under greenhouse conditions (Table 1). In the present test, the isolate was considered pathogenic when it significantly increased percentage of pre-emergence or post-emergence damping-off compared with the control or when it significantly decreases survival, plant height, or dry weight. Of the cotton isolates, only isolate no. 60 was nonpathogenic while 73 isolates were pathogenic representing $98.65 \%$ of the cotton isolates, $76.04 \%$ of the total isolates, and $76.84 \%$ of the pathogenic isolates from all hosts. The pathogenic isolates of the other hosts ranged from four to seven. The distribution of pathogenic $M$. phaseolina isolates based on the five hosts is shown in Table 2. Correlations among variables used for evaluating pathogenicity of $M$. phaseolina isolates are shown in Table 3. The highest correlation was observed between postemergence damping-off and survival. 
Table 2 Distribution of pathogenic isolates of Macrophomina phaseolina based on the host used in isolation.

\begin{tabular}{lccccc}
\hline Host & $\begin{array}{c}\text { No. of tested } \\
\text { isolates }\end{array}$ & $\begin{array}{c}\text { No. of } \\
\text { pathogenic } \\
\text { isolates }\end{array}$ & $\begin{array}{c}\text { Percentage of } \\
\text { isolates from } \\
\text { host }\end{array}$ & $\begin{array}{c}\text { Percentage of } \\
\text { total isolates }^{\text {a }}\end{array}$ & $\begin{array}{l}\text { Percentage of } \\
\text { pathogenic } \\
\text { isolates }\end{array}$ \\
\hline Cotton & 74 & 73 & 98.65 & 76.04 & 76.84 \\
Sesame & 7 & 7 & 100 & 7.29 & 7.37 \\
Sunflower & 5 & 5 & 100 & 5.21 & 5.26 \\
Soybean & 4 & 4 & 100 & 4.17 & 4.21 \\
Flax & 6 & 6 & 100 & 6.25 & 6.31 \\
\hline
\end{tabular}

${ }^{\mathrm{a}} \mathrm{A}$ total of 96 isolates from different hosts were tested for pathogenicity on seedlings of cotton cultivar Giza 89 under greenhouse conditions.

Table 3 Correlation ${ }^{\mathrm{a}}$ among variables used for evaluating pathogenicity of 96 Macrophomina phaseolina isolates on seedlings of cotton cultivar Giza 89 under greenhouse conditions.

\begin{tabular}{lcccc}
\hline & \multicolumn{4}{c}{ Variables } \\
\cline { 2 - 5 } Variables & $\mathbf{1}$ & $\mathbf{2}$ & $\mathbf{3}$ & $\mathbf{4}$ \\
\hline 1. Pre-emergence damping-off $(\%)$ & & & & \\
2. Post-emergence damping-off $(\%)$ & -0.08 & & & \\
3. Survival (\%) & $-0.54^{* *}$ & $-0.69^{* *}$ & & \\
4. Plant height (cm) & -0.10 & $-0.46^{* *}$ & $0.52^{* * *}$ & \\
5. Dry weight (mg/plant) & 0.09 & $-0.30^{* *}$ & $0.27^{* *}$ & $0.60^{* *}$ \\
\hline
\end{tabular}

Liner correlation coefficient $(r)$ is significant at $\mathrm{p} \leq 0.01(* *)$.

\section{Cluster analysis of $M$. phaseolina isolates based on pathogenicity test}

A phenogram based dissimilarily distance (DD) generated from cluster analysis of virulence patterns of M. phasolina isolates is shown in (Fig. 1).

The smaller the DD, the more closely the isolates were related in their virulence patterns. Ten groups (Gs) of similar isolates (from G1 through G10) were identified by cluster analysis. Isolates 42, 76, 33 and 45 showed unique virulent patterns quite different from those of the other isolates. Grouping the isolates by cluster analysis was neither related to their geographic origins nor to hosts.

\section{Cluster analysis of $M$. phaseolina isolates based on AFLP banding patterns}

AFLP analysis was used to evaluate the genetic diversity of the isolates. In this analysis, polymerase chain reaction was performed by using four AFLP primers. Amplification of genomic DNA of all isolates produced large number of distinct amplicons, the size of amplicon was detected by comparing with a DNA ladder ranged approximately from $200 \mathrm{bp}$ to $3500 \mathrm{bp}$. Very rarely, some amplicons were larger than $3500 \mathrm{bp}$. All the primers detected polymorphisms in all the tested isolates. A phenogram based on similarity level (SL) generated from cluster analysis of AFLP banding patterns of M. phasolina isolates is presented (Fig. 2).

The greater the SL, the more closely the isolates were related in their AFLP banding patterns. Twelve groups (from G1 through G12) of similar isolates were identified by cluster analysis. The overall SL among isolates was $20 \%$ while the intraspecific SLs ranged from 40 to $100 \%$. The banding pattern of isolate 87 and 95 were quite different from those of the other isolates. Grouping the isolates by cluster analysis was neither related to their geographic origins nor to hosts. 


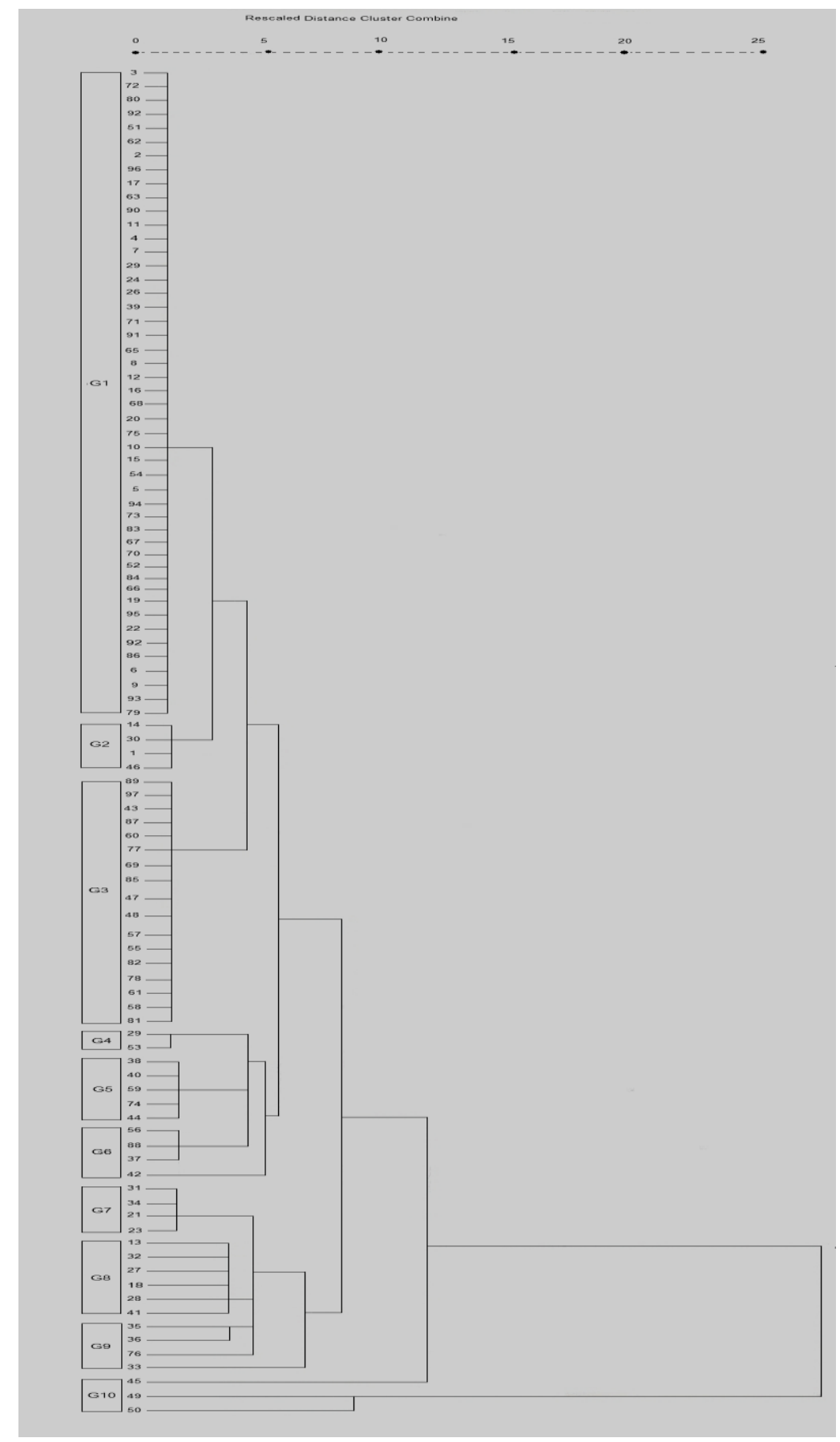

Fig 1 - A phenogram based on average linkage cluster analysis of virulence of 96 isolates of Macrophomina phaseolina on seedlings of cotton cultivar Giza 89. Virulence of isolates was evaluated based on pre-emergence damping-off, post-emergence damping-off, survival, plant height, and dry weight. The isolates were divided into 10 groups (from G1 through G10). 


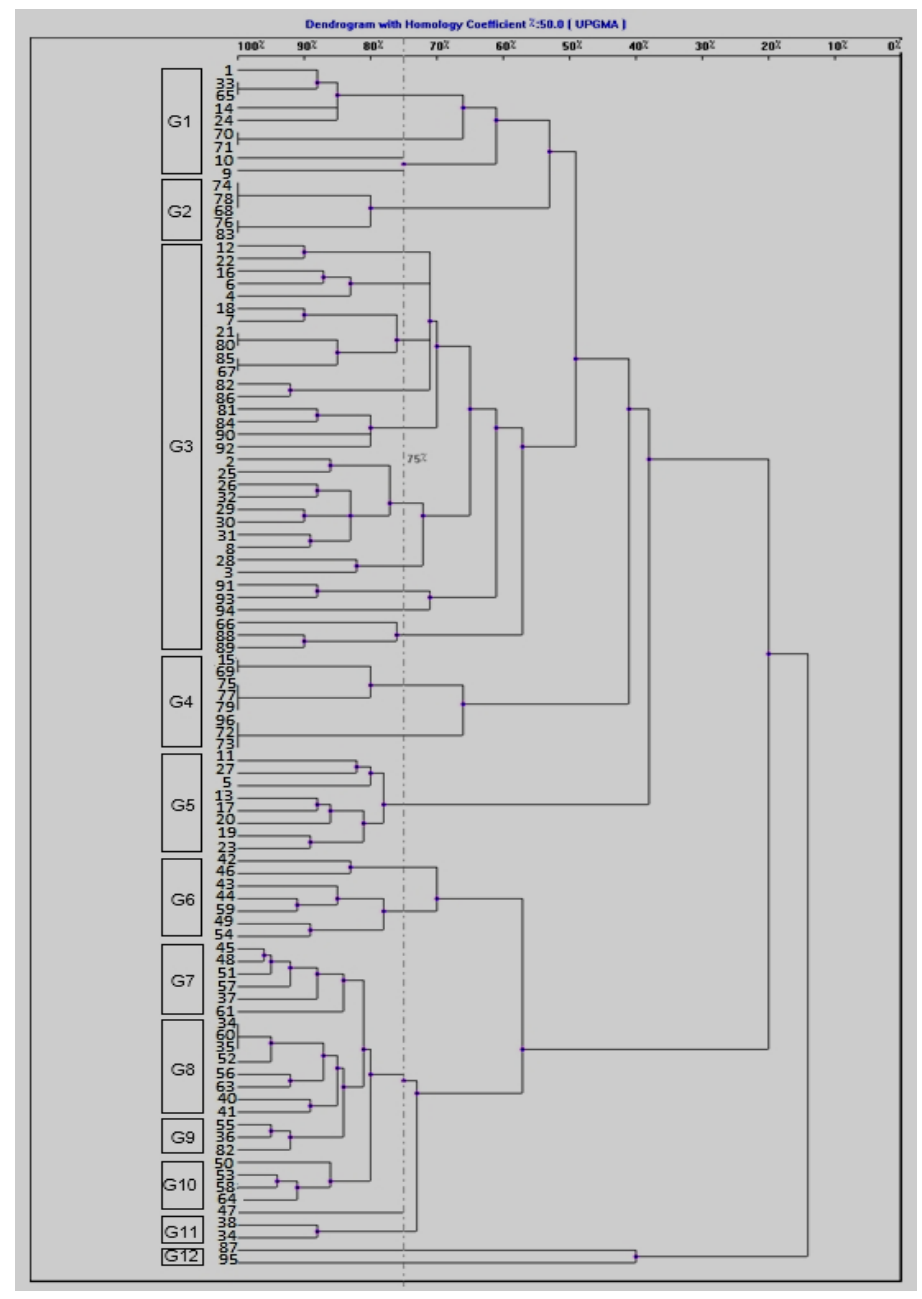

Fig 2 - A phenogram based on cluster analysis of AFLP banding patterns of 96 isolates of Macrophomina phaseolina obtained by four primers and electrophoresed on polyacrylamide gel. The isolates were divided into 12 groups (from G1 through G12).

\section{Discussion}

Although $M$. phaseolina is considered plurivorous, some reports suggested the presence of a general trend to host specialization among M. phaseolina isolates (Saleh et al. 2010, Rayatpanah et al. 2012). For example, Pearson et al. (1986, 1987) used chlorate sensitivity to partition $M$. phaseolina into three physiologically distinct phenotypic groups. These groups were differentially capable of attacking different host plants. Diourte (1987) inoculated sorghum, groundnut, bean and cotton with isolates from each of these hosts. There was a general trend to host preference for the same host isolate. The results of pathogenicity test in the present study did not substantiate these reports because all the isolates, which were recovered from the other hosts (22 isolates) were pathogenic on seedlings of cotton cultivars Giza 89. Giza 75 and Giza 83 yielded $71.24 \%$ of the pathogenic isolates from cotton as they were the two most predominant cultivars in Egypt when the present study was carried out (A.A. Aly, personal observation). Giza 75 was the predominant cultivar in lower Egypt, while Giza 83 was the predominant cultivar in upper Egypt.

Significant correlations were observed between post-emergence damping-off and the variables used in assessing vigour of seedlings (plant height and dry weight). These correlations imply that the higher the disease pressure during the post-emergence stage, the less vigorous would be the surviving seedlings. That is, even the seedlings, which survived post-emergence damping-off suffered from a subtle weakness, which reduced both plant height and dry weight. Evidently, such seedlings would develop into unthrifty and less productive plants (Watkins 1981, Minton \& Garber 
1983). The significant positive correlation between survival and each of plant height and dry weight implies that the lower the disease pressure, the more vigorous would be the seedlings

Conflicting results have reported regarding the relationship between molecular grouping of M. phaseolina isolates and their host or their geographic origin. For example, Mayék-Pérez et al. (2001), Su et al. (2001) and Jane et al. (2003) found some tendencies of M. phaseolina isolates to form groups related to geographic origin. On the contrary, other workers reported molecular grouping of $M$. phaseolina isolates irrespective of host (Babu et al. 2010) and geographic origin (Csondes et al. 2011). In the present study, grouping the isolates by AFLP analysis was neither related to geographic origin nor to host. This result may suggest that $M$. phaseolina isolates from each host or geographic origin were heterogeneous group of isolates.

The present study included only 96 isolates of $M$. phaseolina. It is unlikely that this limited number of isolates represents the full range of variation within this fungus. Despite this limitation, the overall SL among the isolates was as low as $20 \%$, that is, a high level of genetic variation was observed among the isolates. This was surprising because a low level of genetic variation is usually observed in populations of fungi that do not reproduce sexually as occurs with M. phaseolina. However, in retrospect, we speculate that parasexualism with fusion of cells from different hyphae may form hetrokaryons that contribute to the variation identified (Rydholm et al. 2006). Genetic variability in the pathogen population may also reflect the lack of resistance among the currently cultivated commercial cotton cultivars in Egypt (Almeida et al. 2003). The high SLs observed among isolates from different governorates is strong evidence suggesting that such isolates did not evolve independently from each other; therefore, they may be considered as part of the same ancestral population (Almeida et al. 2003). Presumably, the spread of this population from one location to another was by physical means such as seeds, contaminated equipment, soil infested with microsclerotia. The isolates of $M$. phaseolina used in the present study were recovered from five hosts belonging to five genera. Therefore, homogeneity of the AFLP data among isolates from different hosts suggests that selective pressure for host specificity in M. phaseolina in the sampled population had been minimal (Tuskan et al. 1990).

\section{Acknowledgements}

The authors gratefully acknowledge Unit of Excellence in NanoMolecular Plant Pathology Research (ARC), Egypt for funding this study. This work was also partially funded by the Science and Technology Development Fund (STDF), Egypt (STDF-STF program) [grant number 5442].

\section{References}

Abd-Elsalam KA. 2010 - Genetical and biological control of cotton ashy stem caused by Macrophomina phaseolina in outdoor pot experiment. Saudi Journal of Biological Science 17, 147-152.

Abd-Elsalam KA, Bahkali AH, Moslem MA, Amin O, Niessen L. 2011 - An optimized protocol for DNA extraction from wheat seeds and loop-mediated isothermal amplification (LAMP) to detect Fusarium graminearum contamination of wheat grain. International Journal of Molecular Science 12, 3459-3472.

Abd-Elsalam KA, Omar MR, Migheli Q, Nirenberg HI. 2004 - Genetic characterization of Fusarium oxysporum f. sp. vasinfectum isolates by random amplification of polymorphic DNA (RAPD) and amplified fragment length polymorphism (AFLP). Journal of Plant Diseases and Protection 111, 534-544.

Almeida ÁR, Abdelnoor R, Arrabal C, Arias V, Carvalho D, Jacoud Filho S, Marin R, Benato L, Pinto M, Carvalho CP. 2003 - Genotypic diversity among Brazilian isolates of Macrophomina phaseolina revealed by RAPD. Fitopatologia Brasilia 28, 279-285.

Asran-Amal A. 2012 - Molecular identification of Macrophomina phaseolina by microsatellitebased fingerprint. Plant Pathology \& Quarantine 2, 143-151. 
Babu BK, Reddy SS, Yadav MK, Sukumar M, Mishra V, Saxena AK, Arora DK. 2010 - Genetic diversity of Macrophomina phaseolina isolates from certain agro-climatic regions of India by using RAPD markers. Indian Journal of Microbiology 50, 199-204.

Brooker N, Lord JR Long J, Jayawardhana A. 2008 - AFLP analysis of genetic diversity in charcoal rot fungal populations impacted by crop rotations. Communications Agricultural of Applied and Biological Science 73, 7-19.

Creste S, Tulmann-Neto A, Figueira A. 2001 - Detection of single sequence repeat polymorphisms in denaturing polyacrylamide sequencing gels by silver staining. Plant Molecular Biology Reports 19, 299-306.

Csöndes I. 2011 - Mycelial compatibility of Hungarian Macrophomina phaseolina isolates. Acta Agron Hungarica 59, 371-377.

Diourte M. 1987 - Pathogenic Variation and Morphological Studies of Macrophomina phaseolina (Tassi) Goid. MS. Thesis, Texas A and M University College Station, Texas.

Fuhlbohm M. 1997 - Genotypic diversity among Australian isolates of Macrophomina phaseolina. Biennial Australian Plant Pathology Society Conference, Lincoln University, New Zealand.

Huff DR, Bunting TE, Plumley KA. 1994 - Use of random amplified polymorphic DNA markers for the detection of genetic variation in Magnaporthe poae. Phytopathology 84, 1312-1316.

Hyde KD, Abd-Elsalam KA, Cai L. 2010 - Morphology: still essential in a molecular world. Mycotaxon 114, 439-451.

Islam MS, Haque MS, Islam MM, Emdad EM, Halim A, Hossen QM, Hossain MZ, Ahmed B, Rahim S, Rahman MS, Alam MM, Hou S, Wan X, Saito JA, Alam M. 2012 - Tools to kill: genome of one of the most destructive plant pathogenic fungi Macrophomina phaseolina. BMC Genomics 13, 493-509.

Jana TK, Singh NK, Koundal KR, Sharma TR. 2005 - Genetic differentiation of charcoal pathogen rot Macrophomina phaseolina, into specific groups using URP-PCR. Canadian Journal of Microbiology 51, 159-164.

Linhai W, Yanxin Z, Donghua L, Junbin H, Wenliang W, Haixia L, Xiurong Z. 2011 - Variations in the isolates of Macrophomina phaseolina from sesame in China based on amplified fragment length polymorphism (AFLP) and pathogenicity. African Journal of Microbiological Research 5, 5584-5590.

Meyék-Pérez N, López-Castaňeda C, González-Chavira M, Garcia-Espinosa R, Acosta-Gallegos J, Martinréz de la, O Vega, Simpson J. 2001 - Variability of Mexican isolates of Macrophomina phaseolina based on pathogenesis and AFLP genotype. Physiological and Molecular Plant Pathology 59, 257-264.

Mihail JD, Taylor SJ. 1995 - Interpreting variability among isolates for Macrophomina phaseolina in pathogenicity, pycnidium production and chlorate utilization. Canadian Journal of Botany $10,1596-1603$.

Minton EB, Garber RH. 1983 - Controlling the seedling disease complex of cotton. Plant Disease 67, 115-118.

Mohamed HA. 1962 - Effect of date of planting on fungi and other microorganisms isolated from cotton seedlings. Plant Disease Report 46, 801-803.

Mostafa, MA. 1959 - Review of fungal diseases of cotton in Egypt. Egyptian Review Science 3, 155.

Omar MR, Abd-Elsalam KA, Aly AA, El-Samawaty AMA, Verreet J-A. 2007 - Diversity of Macrophomina phaseolina from cotton in Egypt: analysis of pathogenicity, chlorate phenotypes, and molecular characterization. Journal of Plant Disease and Protection 114, 196-204.

Pearson CAS, Leslie JF, Schwenk FW. 1986 - Variable chlorate resistance in Macrophomina phaseolina from corn, soybean and soil. Phytopathology 76, 646-649.

Pearson CAS, Leslie JF, Schwenk FW. 1987 - Host preference correlated with chlorate resistance in Macrophomina phaseolina. Plant Disease 71, 828-831. 
Rayatpanah S, Dalili SA, Yasari E. 2012 - Diversity of Macrophomina phaseolina (Tassi) Goid based on chlorate phenotypes and pathogenicity. International Journal of Biology 4, 54-63.

Rydholm C, Szakacs G, Lutzoni F. 2006 - Low genetic variation and no detectable population structure in Aspergillus fumigates compared to closely related Neosartorya species. Eukaryotic Cell 5, 650-657.

Sabet KA, Khan LD. 1969 - Competitive saprophytic ability and inoculums potential of cotton root-infecting fungi in five soils. Empire Cotton Growing Review 46, 119-133.

Saleh AA, Ahmed HU, Todd TC, Travers SE, Zeller KAF, Leslie J, Garrett KA. 2010 Relatedness of Macrophomina phaseolina isolates from tall grass prairie, maize, soybean and sorghum. Molecular Ecology 19, 79-91.

Su G, Suh SO, Schneider W, Russian JS. 2001 - Host specialization in the charcoal rot fungus, Macrophomina phaseolina. Phytopathology 91, 120-126.

Suriachandraselvan M, Aiyyanthan KEA, Vimala R. 2005 - Host range and cross inoculation studies on Macrophomina phaseolina from sunflower. Madras Agricultural Journal 92, 238240.

Tan DHS, Sigler L, Gibas CFC, Fong IW. 2008 - Disseminated fungal infection in a renal 605 transplant recipient involving Macrophomina phaseolina and Scytalidium dimidiatum: case report and review of taxonomic changes among medically important members of the Botryosphaeriaceae. Medical Mycology 46, 285-292.

Tuskan GA, Walla JA, Lundquist JE. 1990 - enetic-geographic variation in Peridermiam harknessii in the North Central United States. Phytopathology 80, 857-861.

Vandemark G, Martinez O, Pecina V, Alvarado MJ. 2000 - Assessment of genetic relationships among isolates of Macrophomina phaseolina, using a simplified AFLP technique and two different methods of analyses. Mycology 92, 656-664.

Watkins GM. 1981 - Compendium of Cotton Diseases. American Phytopathological Society, St. Paul, MN, USA. 